\title{
STATUS KESEHATAN GIGI DAN MULUT CALON PENGANTIN WANITA (STUDI KASUS: PUSKESMAS KECAMATAN CIPAYUNG JAKARTA TIMUR)
}

\author{
Sigit Nur Indarto ${ }^{1}$, Ni Nyoman Kasihani ${ }^{2}$, Rini Widiyastuti ${ }^{3}$, Rahaju Budiarti ${ }^{4}$, Tedi Purnama ${ }^{5}$ \\ ${ }^{1}$ Puskesmas Kecamatan Cipayung Jakarta Timur, Indonesia \\ 2,3,4,5 Jurusan Keperawatan Gigi Poltekkes Kemenkes Jakarta I, Indonesia

\begin{tabular}{ll}
\hline Info Artikel & Abstrak \\
\hline Genesis Naskah: & Latar belakang: Karies gigi merupakan masalah kesehatan gigi dan mulut yang sering dialami \\
Submitted: 2021-01-26 & oleh hampir seluruh masyarakat di Indonesia. Prevalensi karies gigi nasional 57,8\% dengan \\
Revised: 2021-02-24 & index DMF-T pada usia 15-34 tahun sebesar 2,40. Salah satu kelompok rentan terhadap karies \\
Accepted: 2020-03-03 & gigi adalah ibu hamil dan menyusui menyusui. Karies gigi yang yang tidak dirawat akan \\
& menyebabkan masalah sistemik selama kehamilan dan dapat menyebabkan kelahiran prematur \\
& dan berat bayi rendah. Pelayanan kesehatan bagi calon pengantin merupakan bagian dari \\
\hline Kata Kunci: & pelayanan kesehatan pada masa sebelum hamil, diantaranya pemeriksaan fisik, pemeriksaan \\
Status kesehatan gigi, & laboratorium, pemeriksaan penunjang medis dan pemeriksaan gigi dan mulut. Tujuan: \\
Calon pengantin wanita & Penelitian ini bertujuan untuk mengetahui gambaran status kesehatan gigi dan mulut calon \\
& pengantin wanita di Puskesmas Kecamatan Cipayung Jakarta Timur. Penelitian ini \\
& menggunakan metode deskriptif dengn sampel penelitian menggunakan teknik purvosive \\
& sampling sebanyak 30 responden. Data yang digunakan yaitu data primer dengan melakukan \\
& pemeriksaan gigi pada calon pengantin. Hasil: penelitian menunjukan gambaran status karies \\
& gigi didapatkan, DMF-T rata-rata 2,27 dengan status karies yang paling banyak kategori rendah \\
& (60\%). Seluruh responden melakukan perawatan lanjutan (100\%) dengan perawatan gigi yang \\
& dilakukan scalling 56,7\% dan pemambalan 43,3\%. Kesimpulan: Calon pengantin wanita \\
& memiliki status kesehatan gigi yang kurang baik.
\end{tabular}

DENTAL AND ORAL HEALTH STATUS ON THE BRIDE (CASE STUDY: PUBLIC HEALTH CENTER CIPAYUNG, EAST JAKARTA)

\begin{tabular}{|c|c|}
\hline Keywords: & Abstract \\
\hline $\begin{array}{l}\text { Dental an Oral Health } \\
\text { Status, Bride }\end{array}$ & $\begin{array}{l}\text { Background: Dental caries is a dental and oral health problem that is often experienced by } \\
\text { almost all people in Indonesia. The national dental caries prevalence is } 57.8 \% \text { with the DMF-T } \\
\text { index at the age of } 15-34 \text { years of } 2.40 \text {. One of the groups prone to dental caries is pregnant and } \\
\text { breastfeeding women. Untreated dental caries will cause systemic problems during pregnancy } \\
\text { and can lead to premature birth and low birth weight. Health services for brides-to-be is part of } \\
\text { pre-pregnancy health services, including physical examinations, laboratory examinations, } \\
\text { medical support examinations and dental and oral examinations. Purpose: This study aims to } \\
\text { describe the oral health status of the bride and groom in the Puskesmas, Cipayung District, East } \\
\text { Jakarta. This study used a descriptive method with a research sample of } 30 \text { respondents using } \\
\text { purposive sampling technique. The data used are primary data by conducting dental } \\
\text { examinations on the prospective bride and groom. Results: the study showed a picture of dental } \\
\text { caries status was obtained, the average DMF-T was } 2.27 \text { with the most caries status in the low } \\
\text { category ( } 60 \%) \text {. All respondents performed follow-up care (100\%) with dental care that was } \\
\text { done by scaling } 56.7 \% \text { and filling by } 43.3 \% \text {. Conclusion: the bride has poor dental health status. }\end{array}$ \\
\hline
\end{tabular}

\section{Korespondensi Penulis:}

\section{Tedi Purnama}

Jl. Wijaya Kkusuma No. 47-48 Cilandak Jakarta Selatan

Email: purnamatedy23@gmail.com

(C) Jurusan Keperawatan Gigi Poltekkes Kemenkes Jakarta I Jl. Wijaya Kusuma No. 47-48 Cilandak Jakarta Selatan, Indonesia email: jdht@poltekkesjakarta1.ac.id

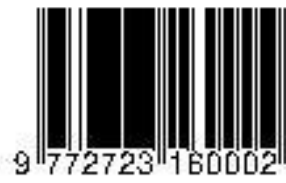




\section{Pendahuluan}

Penyakit gigi dan mulut yang banyak dijumpai di masyarakat Indonesia merupakan penyakit periodontal dan karies gigi (Ari et al., 2018). Hal ini dibuktikan Survei Nasional Riskesdas 2018 melaporkan sebesar $57,8 \%$ penduduk Indonesia mengalami masalah kesehatan gigi; dengan index DMF-T pada usia 15-34 tahun sebesar 2,40 artinya rata-rata jumlah karies gigi sebesar 2 sampai 3 gigi setiap orang (Kemenkes, 2018)

Prevalensi karies cenderung meningkat seiring dengan bertambahnya umur yang berarti adanya kecenderungan penurunan status kesehatan gigi dengan meningkatnya umur. Penelitian Tjahja dan Ghani (2010) pada Puskesmas di Provinsi DKI Jakarta didapatkan nilai DMF-T tinggi > 6 yaitu sebanyak 46,4\%, artinya pengunjung Puskesmas di DKI Jakarta mempunyai riwayat gigi berlubang 6 gigi per orang.

Kelompok rentan terhadap karies gigi adalah: ibu hamil, ibu menyusui, anak usia bawah lima tahun, usia lanjut dan kelompok pekerja (Kemenkes RI, 2012). Pelayanan kesehatan bagi calon pengantin merupakan bagian dari pelayanan kesehatan pada masa sebelum hamil, menurut Peraturan Menteri Kesehatan Nomor 97 tahun 2014 adalah setiap kegiatan dan/atau serangkaian kegiatan yang ditujukan pada perempuan saat remaja hingga saat sebelum hamil dalam rangka menyiapkan perempuan dalam menjalani kehamilan (Kemenkes RI, 2014).

Perubahan hormonal pada saat kehamilan yang disertai adanya faktor lokal seperti plak atau karang gigi akan menimbulkan pembesaran atau peradangan gusi. Sebagian besar ibu hamil menunjukkan perubahan pada gusi selama kehamilan akibat kurangnya kesedaran menjaga kebersihan gigi dan mulut (Kemenkes RI, 2012). Gigi yang berlubang yang tidak dirawat akan menyebabkan masalah sistemik selama kehamilan dan dapat menyebabkan kelahiran prematur dan berat bayi rendah (Suwandi, 2019). Sebagian besar masyarakat belum mengetahui status kesehatannya dikarenakan karena perilaku pemeliharan kesehatan gigi yang masih rendah (Purnama et al, 2019).

Hasil penelitian Saputri et al. (2016) pada ibu hamil di wilayah kerja Puskesmas Kopelma Darussalam Banda Aceh menunjukkan hanya 13

(C) Jurusan Keperawatan Gigi Poltekkes Kemenkes Jakarta I Jl. Wijaya Kusuma No. 47-48 Cilandak Jakarta Selatan, Indonesia email: jdht@poltekkesjakarta1.ac.id responden $(21,7 \%)$ yang memiliki pengetahuan yang baik mengenai pemeliharaan kesehatan gigi dan mulut, sedangkan responden yang memiliki pengetahuan sedang dan buruk masing-masing 27 orang (45\%) dan 20 orang $(33,3 \%)$. Hal ini menunjukkan bahwa sebagian besar ibu hamil hanya fokus pada kehamilannya dan kurang memperhatikan kesehatan gigi dan mulut.

Pemerintah Provinsi DKI Jakarta pada tahun 2017 menerapkan program konseling dan pemeriksaan kesehatan bagi calon pengantin dalam rangka pembinaan ketahanan dan kesejahteraan keluarga. Pemeriksaan kesehatan bagi calon pengantin yang dilaksanakan di Puskesmas atau Rumah Sakit Umum seternpat. Pelayanan kesehatan yang dilakukan diantaranya: pemeriksaan fisik, pemeriksaan laboratorium, pemeriksaan penunjang medis lainnya dan membuat resume hasil pemeriksaan kesehatan termasuk status pemberian imunisasi (Pemerintah Provinsi DKI Jakarta, 2017).

Puskesmas Kecamatan Cipayung merupakan salah satu puskesmas yang memberikan pelayanan kepada calon pengantin, bahkan menambahkan pelayanan tambahan yaitu pelayanan kesehatan gigi. Berdasarkan data laporan penyakit gigi bulan Januari 2019, menunjukkan banyaknya calon pengantin yang mengalami karies gigi atau berlubang.

\section{Metode}

Desain penelitian yang digunakan adalah penelitian secara deskriptif. Populasi dalam penelitian ini adalah seluruh calon pengantin wanita yang melakukan pemeriksaan kesehatan gigi di Puskesmas Kecamatan Cipayung pada bulan MaretApril tahun 2019. Teknik pengambilan sampel menggunakan purposive sampling sebanyak 30 responden dengan kriteria inklusi:

a. Calon pengantin wanita yang melakukan pemeriksaan kesehatan dibuktikan surat pengantar dari Kelurahan

b. Melakukan pemeriksaan pada bulan Maret - April 2019

c. Bersedia menjadi responden

Data yang digunakan dalam penelitian ini adalah data primer yang didapat langsung oleh peneliti

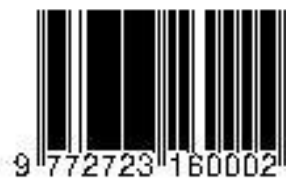


dengan melakukan pemeriksaan karies gigi (DMF-T) pada calon pengantin wanita di poli gigi Puskesmas Kecamatan Cipayung yang kemudian dicatat dilembar status pemeriksaan gigi dan data sekunder dengan menghitung jumlah calon pengantin yang melakukan tindak lanjut perawatan dan pemeriksaan melalui buku register. Penelitian ini diolah dan dianalisa serta disajikan dalam bentuk distribusi frekuensi.

\section{Hasil}

Tabel 1. Distribusi frekuensi karakteristik responden berdasarkan umur

\begin{tabular}{cccc}
\hline No & Umur & $\begin{array}{c}\text { Jumlah } \\
\text { Responden }\end{array}$ & $\begin{array}{c}\text { Persentase } \\
(\boldsymbol{\%})\end{array}$ \\
\hline 1 & $15-20$ Tahun & 9 & $30 \%$ \\
2 & $21-25$ Tahun & 14 & $46,7 \%$ \\
3 & $26-30$ Tahun & 6 & $20 \%$ \\
4 & $31-35$ Tahun & 1 & $3,3 \%$ \\
\hline & Jumlah & 30 & $100 \%$ \\
\hline
\end{tabular}

Tabel 1 menunjukkan bahwa responden dengan umur 15 - 20 tahun sebanyak 9 orang (30\%), umur 21 - 25 tahun sebnyak 14 orang (46,7\%), umur $26-30$ tahun sebanyak 6 orang (20\%) dan umur $31-35$ tahun sebanyak 1 orang $(3,3 \%)$.

Berdasarkan hasil pemeriksaan status karies gigi calon pengantin wanita di Puskesmas Kecamatan Cipayung pada 30 responden didapatkan nilai rata-rata Decay sebesar 1,87, Missing sebesar 0,30, Filling sebesar 0,10 sehingga rata-rata DMF-T sebesar 2,27. Selanjutnya berdasarkan pengelompokkan sesuai kriteria DMF-T menurut target WHO tahun 2010 dapat dilihat pada tabel berikut:

Tabel 2. Gambaran status karies gigi calon pengantin wanita

\begin{tabular}{clcc}
\hline No & Status Karies & $\begin{array}{c}\text { Jumlah } \\
\text { Responden }\end{array}$ & $\begin{array}{c}\text { Persentase } \\
(\boldsymbol{\%})\end{array}$ \\
\hline 1 & Sangat Rendah & 18 & $60 \%$ \\
2 & Rendah & 0 & $0 \%$ \\
3 & Sedang & 5 & $16,7 \%$ \\
4 & Tinggi & 4 & $13,3 \%$ \\
5 & Sangat Tinggi & 3 & $10 \%$ \\
\hline & Jumlah & 30 & 100 \\
\hline
\end{tabular}

(c) Jurusan Keperawatan Gigi Poltekkes Kemenkes Jakarta I Jl. Wijaya Kusuma No. 47-48 Cilandak Jakarta Selatan, Indonesia email: jdht@poltekkesjakarta1.ac.id
Tabel 2 menunjukkan bahwa responden yang mempunyai status karies sangat rendah sebanyak 18 orang $(60 \%)$, status karies sedang sebanyak 5 orang (16,7\%), status karies tinggi sebanyak 4 orang $(13,3 \%)$ dan status karies sangat tinggi sebanyak 3 orang $(10 \%)$.

Tabel 3. Gambaran jenis perawatan gigi pada calon pengantin wanita

\begin{tabular}{clc}
\hline No & Jenis Perawatan & Jumlah \\
\hline 1 & Penambalan, scalling, & 12 \\
& pencabutan & \\
2 & Penambalan & 13 \\
3 & Scalling & 17 \\
4 & Pencabutan & 0 \\
\hline
\end{tabular}

Tabel 3 menunjukkan bahwa responden yang melakukan seharusnya melakukan tindak lanjut perawatan penambalan sebanyak 12 orang, responden yang melakukan scalling sebanyak 17 orang dan tidak terdapat responden yang melakukan pencabutan gigi.

Tabel 4. Gambaran karang gigi gigi pada calon pengantin wanita

\begin{tabular}{cccc}
\hline No & Karang Gigi & $\begin{array}{c}\text { Jumlah } \\
\text { Responden }\end{array}$ & $\begin{array}{c}\text { Persentase } \\
\mathbf{( \% )}\end{array}$ \\
\hline 1 & Ya & 29 & $96,7 \%$ \\
2 & Tidak & 1 & $3,3 \%$ \\
\hline & Jumlah & 30 & 100 \\
\hline
\end{tabular}

Tabel 4 menunjukkan bahwa responden yang mempunyai karang gigi sebanyak 29 orang (96,7\%) dan responden yang tidak mempunyai karang gigi sebanyak 1 orang $(3,3 \%)$.

Tabel 5. Gambaran tindak lanjut perawatan gigi pada calon pengantin wanita

\begin{tabular}{clcc}
\hline No & Tindak Lanjut & $\begin{array}{c}\text { Jumlah } \\
\text { Responden }\end{array}$ & $\begin{array}{c}\text { Persentase } \\
(\mathbf{\%})\end{array}$ \\
\hline 1 & Penambalan & 13 & $43,3 \%$ \\
2 & Scalling & 17 & $56,7 \%$ \\
3 & Pencabutan & 0 & $0 \%$ \\
\hline & Jumlah & 30 & 100 \\
\hline
\end{tabular}

Tabel 5 menunjukkan bahwa responden yang melakukan perawatan sebanyak 30 orang (100\%)

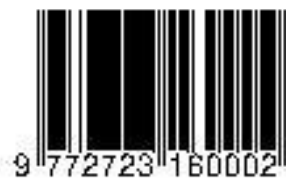


dengan penambalan 13 orang (43,3\%) dan scalling 17 orang $(57,7 \%)$.

\section{Pembahasan}

Dari hasil penelitian didapatkan usia calon pengantin wanita sebagian besar berusia $21-25$ tahun sebesar $46,7 \%$. Hal ini sesuai dengan aturan dalam pemerintah yang menyatakan batas minimal usia menikah pada perempuan adalah 20 tahun. Batasan usia ini dianggap telah siap, baik dipandang dari sisi kesehatan maupun perkembangan emosional untuk menghadapi kehidupan berkeluarga. Kematian maternal pada wanita hamil dan melahirkan pada usia dibawah 20 tahun ternyata $2-5$ kali lebih tinggi daripada kematian maternal yang terjadi pada usia 2029 tahun (Meisuri et al, 2018).

Hasil penelitian tentang status karies gigi didapatkan rata-rata DMF-T sebesar 2,27 artinya setiap calon pengantin memiliki pengalaman karies gigi sebanyak 2-3 gigi per orang. Berdasarkan kriteria WHO sebagaian besar responden yang mempunyai status karies sangat rendah sebesar yaitu $60 \%$. Hal ini dimungkinkan karena calon pengantin mayoritas berusia 21 - 25 tahun. Kerusakan gigi merupakan proses kemoparasiter yang disebabkan oleh terbentuknya asam melalui proses fermentasi karbohidrat oleh bakteri sehingga terjadi dekalsifikasi email dan dentin. Asam akan melarutkan residu dari email dan dentin yang mengalami dekalsifikasi sehingga terbentuk lubang pada gigi (Dewi \& Kamelia, 2016). Didukung pendapat Tarigan (2013), menyatakan keadaan atau kondisi gigi kelompok usia muda lebih baik dibandingkan kelompok usia tua, artinya semakin bertambah umur seseorang berisiko terkena karies. Diperkuat juga oleh pendapat Notohartojo et al. (2011) menyatakan bahwa karies gigi dipengaruhi oleh faktor usia. Semakin tua usia, semakin mudah terkena karies gigi, begitu juga sebaliknya semakin muda jarang terkena karies hal ini ditunjukkan dengan rendahnya indeks DMF-T pada calon pengantin wanita.

Hasil penelitian dari 30 responden didapatkan sebagian besar responden mempunyai karang gigi yaitu $96,7 \%$, hal ini dimungkinkan karena kurangnya pengetahuan tentang pemeliharaan kebersihan gigi dan mulut. Sejalan juga dengan pendapat Notoatmodjo

(C) Jurusan Keperawatan Gigi Poltekkes Kemenkes Jakarta I Jl. Wijaya Kusuma No. 47-48 Cilandak Jakarta Selatan, Indonesia email: jdht@poltekkesjakarta1.ac.id
(2010) menyatakan pengetahuan merupakan domain yang sangat penting untuk terbentuknya tindakan seseorang. Pengetahuan mengenai kesehatan gigi dan mulut sangat penting untuk terbentuknya tindakan menjaga kebersihan gigi dan mulut. Menjaga kebersihan gigi merupakan salah satu cara dalam meningkatkan kesehatan gigi (Saputri et al., 2016).

Hasil penelitian tentang tindak lanjut perawatan pada calon pengantin wanita di Puskesmas Kecamatan Cipayung didapatkan responden yang melakukan penambalan sebanyak $43,3 \%$ dan scalling sebanyak $56,7 \%$, artinya seluruh calon pengantin melakukan tindak lanjut perawatan (100\%). Hal ini mungkin dikarenakan pemberian informasi tindak lanjut dari peneliti yang jelas sehingga responden mengikuti rekomendasi perawatan lanjutannya. Selain itu juga dimungkinkan karena responden merasa puas terhadap pelayanan yang diberikan, hal ini sesuai pendapat Sembel et al., (2014) menyatakan ada dua faktor utama yang mempengaruhi kualitas jasa pelayanan atas jaminan yang dirasakan pasien yaitu expected service dan perceived service. Apabila pelayanan yang diterima atau dirasakan dapat menjamin pasien, maka kualitas jasa pelayanan akan dipersepsikan memuaskan. Sebaliknya jika jaminan atas kualitas jasa yang diterima lebih rendah daripada yang diharapkan, maka kualitas pelayanan kesehatan akan dipersepsikan buruk atau tidak memuaskan. Sehubungan dengan kemungkinan pelayanan yang memuaskan maka pasien calon pengantin kembali melakukan tindak lanjut perawatan di Puskesmas Kecamatan Cipayung. Sebagaian besar tindak lanjut yang dilakukan adalah scalling dan penambalan sehingga menambah kepercayaan diri calon pengantin dan terhindar dari penyakit gigi dan mulut misalnya halitosis dan gingivitis.

\section{Kesimpulan dan Saran}

Berdasarkan hasil penelitian, dapat disimpulkan bahwa:

1. Status karies gigi pada calon pengantin wanita, didapatkan DMF-T rata-rata 2,27 yang artinya setiap calon pengantin wanita terdapat 2-3 gigi yang mengalami karies, sebagian besar responden memiliki pengalaman karies gigi termasuk kategori sangat rendah.

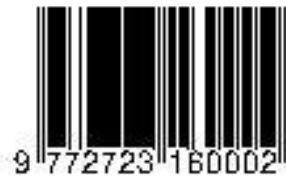


2. Sebagian besar jenis perawatan gigi pada calon pengantin wanita, yang seharusnya dilakukan adalah pembersihan karang gigi (scalling) sebesar $56,7 \%$

3. Sebagaian besar calon pengantin wanita mempunyai karang gigi sebanyak sebanyak $96,7 \%$

4. Persentase calon pengantin wanita yang melakukan tindak lanjut perawatan sebesar $100 \%$ dan sebagian besar tindak lanjut perawatan yang dilakukan adalah scalling.

Sehubungan dengan hasil penelitian maka dapat disarankan sebagai berikut:

1. Disarankan bagi calon pengantin wanita untuk menjaga kesehatan gigi dan mulutnya, dengan cara menyikat gigi minimal 2 kali sehari setelah sarapan dan sebelum tidur serta melakukan kontrol ke klinik gigi minimal 6 bulan sekali.

2. Bagi Puskesmas Cipayung Perlu konsistensi dalam penyelenggaraan program pemeriksaan kesehatan gigi bagi calon pengantin wanita supaya calon pengantin dapat meningkatkan derajat kesehatan gigi dan mulutnya.

\section{Daftar Pustaka}

Ari, I. D., Kamelia, E., Miko, H. (2018). Pengaruh Berkumur Larutan Madu Terhadap Gingivitis pada Siswa Kelas VIII MTSN 3 Kota Tasikmalaya. Actual Research Science Academic, 3(2), 1-9.

Dewi, T. K., Kamelia, E. (2016). Hubungan PH saliva dengan DMF-T Pada mahasiswa tingkat I program DIII Keperawatan Gigi Poltekkes Kemenkes Tasikmalaya. Media Informasi, 12(1), 115-119.

Kemenkes, R. I. (2018). Hasil Utama Riset Kesehatan Dasar Tahun 2018. Kementrian Kesehatan Republik Indonesia, 1-100.

Kementerian Kesehatan. (2014). PMK No.97 Tahun 2014 Tentang Pelayanan Kesehatan. Artikel, [cited 2018 Jan 7]; 3-8.

Kementerian Kesehatan RI. (2012). Pedoman Pemeliharaan Kesehatan Gigi dan Mulut Ibu Hamil dan Anak Usia Balita Bagi Tenaga Kesehatan di Fasilitas Pelayanan Kesehatan. In Kemenkes RI.

Meisuri, N. P., Irianto, M. G., Ungu, B. (2018). Faktor

(C) Jurusan Keperawatan Gigi Poltekkes Kemenkes Jakarta I Jl. Wijaya Kusuma No. 47-48 Cilandak Jakarta Selatan, Indonesia email: jdht@poltekkesjakarta1.ac.id
Determinan yang Mempengaruhi Kejadian Kematian Perinatal. Jurnal Majority, 7(3), 121127.

Notoatmodjo, S. (2010). Ilmu perilaku kesehatan. Jakarta: Rineka Cipta, 200, 26-35.

Notohartojo, I. T., Suratri, M. A. L., Riyadina, W., Nainggolan, O. (2011). Nilai Karies Gigi pada Karyawan Kawasan Industri di Pulo Gadung Jakarta. Media Penelitian Dan Pengembangan Kesehatan, 21(4).

Pemerintah Provinsi DKI Jakarta. (2017). Peraturan Gubernur Provinsi Daerah Khusus Ibukota Jakarta Nomor 185 Tahun 2017 Tentang Konseling dan Pemeriksaan Kesehatan Bagi Calon Pengantin. 583-606.

Purnama, T., Rasipin, R., Santoso, B. (2019). Pengaruh Pelatihan Tedi's Behavior Change Model pada Guru dan Orang Tua terhadap Keterampilan Menggosok Gigi Anak Prasekolah. Quality: Jurnal Kesehatan, 13(2), 75-81.

Saputri, D., Afrina, A., Shalina, R. K. (2016). Perilaku Pemeliharaan Kesehatan Gigi dan Mulut Ibu Hamil di Wilayah Kerja Puskesmas Kopelma Darussalam Banda Aceh. Journal Of Syiah Kuala Dentistry Society, 1(1), 85-90.

Sembel, M., Opod, H., Hutagalung, B. S. P. (2014). Gambaran tingkat kepuasan pasien terhadap perawatan gigi dan mulut di puskesmas Bahu. EGiGi, 2(2).

Suwandi, T. (2019). Hubungan Penyakit Periodontal pada Kehamilan dengan Kelahiran Bayi Prematur. Jurnal Kedokteran Gigi Terpadu, 1(1).

Tarigan, R. (2013). Karies gigi. Jakarta: EGC.

Tjahja, I., Ghani, L. (2010). Status Kebersihan Gigi dan Mulut Ditinjau dari Faktor Individu Pengunjung Puskesmas DKI Jakarta Tahun 2007. Buletin Penelitian Kesehatan, 38(2), 52-66. 